\title{
Wild animals (fish and wildmeat) contribute to dietary diversity among food insecure urban teenagers - the case of Quibdó, Colombia
}

Nathalie van Vliet 1*; Björn Schulte-Herbruggen 2; Liliana Vanegas 3; Eric Yair-Cuesta 4; François Sandrin 5; Robert Nasi 6

\begin{abstract}
Many urban areas located at the forest edge maintain a high connection to the forest, either because forests provide resources and services that act as safety nets for the poor or because they represent a cultural link to traditional lifestyles. However, in conflict areas, this link to the forest may have been disrupted, either because conflict exacerbates forest degradation, or because people are alienated from their lands by the conflict and have therefore less access to forest resources, or because the frequent movement of people from towns to rural areas and backwards is limited by insecurity and poor transportation means. In this study, we assessed the nutritional status of teenagers living in Quibdó, a forest town that lies at the centre of Colombia's long history of political conflicts, and analysed the role that wild animals (wild fish and wildmeat) still play on their food security. While our analysis clearly showed that wild animals significantly contribute to dietary diversity, food and nutrition insecurity prevailed among teenagers, especially among the poorest families. Our results suggested that postconflict policies should explicitly promote integrated approaches to reduce food insecurity and value biodiversity for its role in reducing malnutrition.
\end{abstract}

Keywords: Wild Animals; Food Security; Biodiversity; Forest Towns; Conflict; Colombia

1 CIFOR, Carrera 5 \#26A-47, Bogota, Colombia.

2 Independant consultant

3 Fundación SI, Calle 28 No. 13A-24 Oficina 308, Bogotá, Colombia.

4 Instituto de Investigaciones del Pacífico, Cra 6 No 37-39, Quibdó, Choco, Colombia

5 Fundación SI, Calle 28 No. 13A-24 Oficina 308, Bogotá, Colombia.

6 Jalan CIFOR, Situ Gede, Sindang Barang, Bogor (Barat) 16115, Indonesia.

* Corresponding author. $\square$ E-mail address: NVV 1 (vanvlietnathalie@yahoo.com), BSH (bsh@posteo.de), LV (lilovan7@gmail.com), ECR (cuestarios@gmail.com), FS (f.sandrin1990@gmail.com), RN (r.nascgiar.org) 


\section{INTRODUCTION}

At least one billion people worldwide depend on wild foods for their food security (Hickey et al., 2016). Wild foods diversify diets, are a source of nutrient, improve palatability of staple foods and generate cash income (Burlingame, 2000; Arnold \& Perez, 2001; Sunderland, 2011; Shumsky et al., 2014). They are also important safety nets during periods of shortage or shock (Arnold et al., 2011; Vinceti et al., 2013; Reyes-García et al., 2015; Wunder et al., 2014; Schulte-Herbrüggen et al., 2013), especially amongst the poor living in rural, forested areas (Shackleton \& Shackleton, 2004). Several authors have described the diversity of wild foods used across the tropics both among rural and urban dwellers (Bharucha \& Pretty, 2010), including wild vegetables (Bvenura \& Afolayan, 2015; Valderrama et al., 2014) and wild animal species (Nasi et al., 2011; Scoones et al., 1992; Vargas-Tovar, 2014). Wild foods, especially wildmeat and fish, are important contributors to dietary diversity, even when consumption frequencies are low (Golden et al., 2011; Sarti et al., 2015; Shackleton et al., 2015; van Vliet et al., 2015).

In conflict areas, two main factors may affect the use of wild foods: 1. Degradation of forests and biodiversity; 2 . the level of access to natural environments (Seligman et al., 2010; Kasper et al., 2014). Indeed, wars and conflict are considered among the most important drivers of the depletion of natural resources (Dudley et al., 2002; Hatton et al., 2001; Yamigawa, 2003; Nackoney et al., 2014; Vogel, 2000; Lawrence et al., 2015). For example, the available literature shows that hunting and deforestation may increase in some regions during periods of political instability due to a breakdown in law enforcement and reduced availability of alternative food (Beyers et al., 2011; Campbell et al., 2008; Kalpers et al., 2003; Plumptre et al., 1997; de Merode et al., 2007). On the other hand, conflicts may also reduce access to wild sources of food (Dudley et al., 2002; de Merode et al., 2004; Brncic et al., 2010; Baptiste et al., 2017), due to displacement or to nature conservation measures imposed by armed groups to the local population, as observed in Colombia (Baptiste et al., 2017).

In this paper, our objective was to assess the role of wild animals in supporting food security in urban areas affected by decades of armed conflict, where both forest degradation and deprived access to natural resources are a reality. Our work focused on Quibdó, Colombia and our target group for this study were teen-agers (14 to 18 years old), given their vulnerability to food insecurity (e.g more likely to experience mental health problems when experiencing food insecurity (Poole-Di Salvo et al., 2016). Based on anthropometric measures and children's perceptions of their own food security, we first assessed the general level of food security and nutritional status of the children, then analysed the socio-economic determinants of food security and nutritional status. Finally, we assessed the contribution of wild animals to food security with the hypothesis that wild animals were still present in the diets despite the above mentioned context, particularly among the poorest.

1 Defined as the access at all times to sufficient, safe, nutritious food to maintain a healthy and active life (FAO, 1996). 


\section{MATERIAL AND METHODS}

\section{Geographic description of the study area}

The department of Chocó covers $4 \%$ of the national territory of Colombia and is located between the forest blocks of Darién and the basins of the Atrato and San Juan rivers (IGAC 2006). Chocó is known for its diverse geography, unique ecosystems and is considered one of the most biodiverse regions of the world, with its biodiversity being of great cultural and socio-economic importance (Pino et al., 2004). However, despite this environmentally rich context, the human population of Chocó is largely impoverished (DANE, 2010). According to the National Administrative Department of Statistics (DANE, 2010), the department of Chocó has the highest rate of unmet basic needs within Colombia (79.2\%), the highest poverty rate of the country $(49,9 \%)$ and the highest unemployment rate $(18,2 \%$, versus $8,8 \%$ in the national territory) (Defensoría del pueblo de Colombia, 2014). Additionally, according to the 2010 National Nutrition Situation Survey, Chocó is the second department with the highest food insecurity in the country (Fonseca-Centeno et al., 2011).

For decades, the Chocó department has been plagued by illegal armed groups because of its strategic geographic position (easy access to both Pacific and Atlantic coasts, and to the key drug trading departments of Antioquia and Risaralda). Since the second half of the 1980s, actions of the guerilla combined with paramilitary incursions contributed to a large-scale displacement of people to Quibdó (Escobedo \& Guía, 2015). Within the last 25 years, the town of Quibdó has grown very rapidly and currently counts with a population of 116,000 inhabitants (DANE, 2010). The population in Quibdó is composed of afro-descendants $(90 \%$ of the population), indigenous communities $(6 \%)$, mestizos (4\%) and whites (less than 1\%). In the past ten years, Quibdó has recorded an unusual increase in violence, primarily due to disputes over gold mining (Idrobo et al., 2014, Escobedo \& Guía, 2015).

\section{Sampling design}

To assess the food security status of children, the socio-economic determinants of food security and the contribution of wild animals, we interviewed and obtained anthropometric measures from 963 pupils, aged between 14 and 18 years, at 16 out of the 22 private and public secondary schools listed by the SINEB (Information system for national primary and secondary education). Engaging pupils at schools in data collection is a commonly used and an efficient data collection procedure (Hadley et al., 2009; Niclasen et al., 2013; van Vliet et al., 2014; van Vliet et al., 2015; Vanegas et al., 2015). For a description of the socio-economic characteristics of the sample see Table 1.

The sampled schools comprised diverse catchments that are representative of the urban population, including "conflict schools" $(\mathrm{N}=4)$ neighbourhoods with largely displaced families experiencing high levels of poverty and challenging social backgrounds (conflict and common street violence problems) (Yair E., pers. Comm, Instituto de Investigaciones del Pacifico (IIAP)). It also included "mixed schools" whose catchment contains families with mixed backgrounds that can be described as representative of poor to relatively wealthy households but with substantially lower exposure to past conflicts (Yair, pers.com, IIAP). While we aimed to include a broad sample of children with 
Table 1: List of explanatory variables used to define the socio-economic background of respondants

\begin{tabular}{|c|c|c|}
\hline Explanatory variables & Structure & Summary \\
\hline Gender of respondent & Binary & Male $=44.76 \%$, Female $=55.24 \%$ \\
\hline Age of respondent & Continuous & Mean $=15.06, \mathrm{StD}=1.61$, Range $=12-18$ \\
\hline Ethnicity of respondent & Binary & Afro $=88.16 \%$, Non-afro $=11.84 \%$ \\
\hline Type of school & Binary & mixed $=22.32 \%$, conflict $=77.68 \%$ \\
\hline Gender of household head & Binary & Male $=36.14 \%$, Female $=63.86 \%$ \\
\hline Both parents present & Binary & Yes $=83.70 \%, \mathrm{No}=16.30 \%$ \\
\hline $\begin{array}{l}\text { All parents present are employed } \\
\text { or self-employed }\end{array}$ & Binary & $\begin{array}{l}\text { Yes: } 56.29 \% \\
\text { No: } 43.71 \%\end{array}$ \\
\hline Parents mining & Binary & $\begin{array}{l}\text { Yes }=13.40 \%, \mathrm{No}=86.60 \\
\%\end{array}$ \\
\hline Number of household members & Continuous & Mean $=5.23, \mathrm{StD}=2.48$, Range $=1-20$ \\
\hline $\begin{array}{l}\text { Household dependence ratio } \\
\text { (number of children/total number } \\
\text { of hh members) }\end{array}$ & Continuous & Mean $=0.43, \mathrm{StD}=0.16$, Range $=0.13-1$ \\
\hline Household asset wealth group ${ }^{1}$ & Factor & $1-5$ \\
\hline
\end{tabular}

different backgrounds, we acknowledge that our sample focuses on children attending secondary school and hence may exclude the most vulnerable children, ie those not able to attend school. In the context of Quibdo, poverty levels contribute to a high dropout rate $(15.4 \%$ compared to the $4.8 \%$ in the national territory) and $29.2 \%$ of the children are without access to education (Alcaldia de Quibdo, 2014). We therefore see our results about the contribution of biodiversity to food security as a conservative estimate, since we may not have sampled the most vulnerable children.

\section{Ethical issues and data quality}

Children are vulnerable members of society, requiring special precautions when included in research. Our strategy for minimizing the risk of harm to respondents included multiple strategies. First, we had our research proposal reviewed and approved by the independent ethical review board of the Center for International Forestry Research (CIFOR). Second, we obtained authorizations from the school directors, class teachers, and informed consent from the pupils. We also obtained oral consent from parents during information meetings organized prior to the activity to inform the parents about the objective of the activity, 
how it contributed to the general curriculum of the class and allowing parents to ask questions and give or withdraw their consent (all parents gave their consent). The activity with each class included two modules (1. Semi-structured interview and 2. anthropometric measures) and was integrated into the curriculum of the school and therefore carried out in the natural science class with the presence of a teacher.

Each module was facilitated by the research team (one main researcher with a biodiversity and livelihoods background and experience working with children, and two research assistants: biologists trained on nutrition issues). The first module involved a short introduction presenting the aim of the research activity, allowing participation based on informed consent. All data collection was carried out using KoBoCollect (www.KoBoToolbox.org), a freely available and open source software installed on tablets distributed to students. During the class, the researchers explained the use of the app on the tablets and provided a tablet with the questionnaire to each student. To ensure a good understanding of each of the questions, the researcher first read the question, explained it to the class and all students responded to the question at the same time, before moving to the next question. For example, when addressing conceptually difficult topics like household membership, we took great care to clearly explain the definition used and ensured that children understood what we referred to. In addition, to ensure the accuracy and independence of the information, students were asked to answer the questionnaire in a strictly individual manner, directly answering using the tablet and in silence, with the presence of the research team and the class teacher. After collecting data in the mobile devices, the data was automatically uploaded to the server of KoBoToolbox.org from which it was downloaded for analysis. Due to the design of this data collection process, interference from the teacher and other pupils was minimized. Also, as the data was directly uploaded only the respondent could see the responses, minimizing potential harm to the children from others. The advantages of using an app as compared as paper interviews also include the fact that the entry of information is quicker and errors usually made during the transcription are avoided.

\section{Semi-structured interview}

The semi-structured interview conducted with the help of KoBoCollect was divided into four sections and elicited information about both the respondent and his/her household:

1. Socio-economic information (Respondent's age, place of residence and ethnicity. Parents' occupation, gender of the household head, number of adults in the household, household dependents, housing characteristics, household assets) (Table 1). The list of household assets chosen for the questionnaire was carefully developed to gather information on the best locally applicable indicators of household wealth, while ensuring that these could be answered by young household members. The list was developed by the research team based on recommendations from a multi-disciplinary expert group composed of researchers from the IIAP (Instituto de Investigaciones Ambientales del Pacífico) and local technical institutions (from the health and education sectors). Based on the socio-economic variables used in the questionnaire, we calculated a household wealth index based on the household assets mentioned by the children. In calculating household wealth 


$$
A_{i}=\left(\beta_{1} a_{1 i}\right)+\left(\beta_{2} a_{2 i}\right)+\left(\beta_{3} a_{3 i}\right)+\ldots+\left(\beta_{k} a_{k i}\right)
$$

index ( $\mathrm{Ai}$ ) for each child (I), we followed the method described by Cinner et al., (2012), whereby k PCA derived loadings (Aki) are used as weights and multiplied by $\beta$ that is a binary value $(0 / 1)$ stating whether or not a child's household (i) owns asset $k$.

2. Perceived level of food security. To obtain information on the respondents' own perception of his/her level of food security, we used a method commonly applied by international development agencies in field assessments (Connel et al., 2004). The method is non-intrusive, relatively quick and has been shown to correlate well with more in-depth assessment. We asked children : 1) how do you consider the quality and amount of food you eat at home? very low/low/normal/very good; 2) do you worry that food can become scarce at home before your parents can purchase or get more food ?; 3) Is food scarce at home due to lack of money; 4) do you feel hungry at times; 5 ) if food becomes scarce, does your family purchase cheaper food items?; 6) do you happen to skip one meal when food becomes scarce at home ; 7) do you happen to skip eating for one day when food becomes scarce at home?.

3. Food diversity score and animal food diversity index, based on consumption during the day preceding the interview. The food diversity score was based on binary responses (yes/no) to 11 food groups: 1) Cereals and grains, 2) fish and seafood, 3) eggs, 4) meat, poultry or offal, 5) starchy food, 6) vegetables, 7) fruits, 8) milk and dairy products, 9) oil/fats, 10) sugar/honey. Following Swindale \& Bilinsky (2006), we calculated food diversity scores as the sum of the number of food groups consumed by an interviewee during the day before the interview divided by the total number of food groups (11).

For children that responded "yes" to food category 2 (fish and seafood) and 4 (meat, poultry or offal), we further asked the origin

$$
H=-\Sigma(p i * \ln (p i))
$$

of the fish/meat (wild or domestic) and the species consumed. Based on this information, an animal protein diversity index was calculated for the whole sample based on the Shannon diversity index (van Vliet et al. 2014):

where $\mathrm{H}$ is the index of diversity and pi is the percentage of meals with animal protein i.

In the first calculation of the animal protein diversity index $(\mathrm{H} 1)$, we did not include wild animals (wild fish or wildmeat). In the second calculation of animal protein diversity index (H2), we included wild proteins and accounted for the diversity of species used considering each species as a different protein type $(\mathrm{H} 2)$.

\section{Anthropometric measures}

The second module of the activity consisted in measuring two classic noninvasive anthropometric measures (weight and height) (WHO working group 1986). Height (in $\mathrm{cm}$ ) was measured with a meter stick to the nearest $\mathrm{cm}$ and weight (in $\mathrm{kg}$ ) was measured with a digital weighing scale (®Beurer, model BG 21) to the nearest gram. Only one pupil refused to be measured and was subsequently excluded from the analysis. Using the anthropometric data, we calculated the Body Mass Index (BMI) for each child as a proxy for nutritional status (Baley \& Ferro-Luzzi, 1995): BMI = weight $(\mathrm{kg})$ divided by height $(\mathrm{cm})$. Using 
criteria for children between 5 and 18 years (Lleras 2010), we classified a child as severely underweight, underweight, normal, overweight or obese, according to age and gender. We also calculated the Height/Age ratio and classified children in three categories: height too low for age, risk of low height and normal height for age (following Lleras 2010).

\section{Statistical analysis}

All statistical analyses were conducted using $\mathrm{R}$ version 3.3.2 ( $\mathrm{R}$ Development Core Team 2016).

\section{-Socio-economic determinants of food security}

To assess the relationship between socioeconomic variables and food security and nutritional status variables (BMI, height/age ratio, food diversity score, multiple indicators of food security perception) we used binomial Generalized Linear Models (GLM) with logit link function in the stats package version 3.3.2. Non-binomial response variables were first converted into binary variables. BMI categories "severely underweight", "underweight", "overweight" or "obese" were grouped together into a "nonaverage" category and compared to the "Average" category. Height for age categories "height too low for age" and "risk of low height" were grouped together and compared to "normal height for age". Food security perception categories "very low" and "low" were grouped together and compared to "normal" and "very good".

The explanatoryvariables used for the analysis included generic social variables of the child (age (numerical), gender (binary factor: male, female) and ethnicity (binary factor: afro, not afro), conflict related variables (gender of the household head (binary factor: male, female), whether one or both parents were present (binary factor: yes, no), type of school (binary factor: conflict school, not conflict school); one or two parents involved in mining (binary factor: yes, no)) and poverty related variables (whether any of the present parents were un-employed (binary factor: yes, no), number of household members (numerical), household dependence ratio (numerical), and household wealth group (categorical factor: 1-2-3-4-5)). Where we found an effect of household wealth on the response variable we used a posthoc Tukey test in the multcomp package (Version 1.4-6) to compare between different factor levels.

\section{-Contribution of wild foods to food security}

We calculated the percentage of children that consumed each type of animal protein (particularly wild fish and wildmeat). We listed the different species of wild fish and wild meat consumed by the children based on the 24 hour-recall.

To test for significant effects of wild animal consumption (wild fish and wild meat) on food security and nutritional status variables (BMI, height/age ratio, food diversity score, perception of food security) we used binomial Generalized Linear Models (GLM) with logit link function in the stats package version 3.3.2. We assessed the socio-economic determinants of wild animal consumption using the same socioeconomic variables mentioned above.

\section{RESULTS}

\section{Food security of children}

Overall, interviewed children showed a 
high level of perceived food insecurity (poor quality or/and quantity of food). Nearly half of respondents $(45 \%)$ perceived their food security as low and $33 \%$ considered it very low (Table 2). A total of $60 \%$ of the children stated that their parents lacked money to purchase sufficient amounts of food. More than one third of the children $(37 \%)$ stated feeling hungry at times because there was nothing to eat at home. Among the strategies used when food becomes scarce at home, the children mentioned: eating cheap food ( $76 \%$ of the children), eating less (46\%), skipping a meal $(30 \%)$, stop eating during one day $(18 \%)$.

The mean food diversity score among children was equal to 5,6 out of 11 $(s d=1.88)$. The day before the interview, the majority of children had eaten meat/poultry/offal or fish $(90 \%)$, sweets/honey (63\%) and cereals (61\%). Dairy products were consumed by $49 \%$ of the children, fat by $46 \%$, fruits by $39 \%$, starchy food by $36 \%$, legumes by $30 \%$ and grains by $27 \%$.

Using the body mass index (BMI) as a proxy for the nutritional status of children showed the co-existence of both underweight and obese children. A total of $20.6 \%$ of the children were obese $(5.6 \%)$ or overweight $(15.0 \%)$ and $14.0 \%$ of the children were either underweight $(11.3 \%)$ or severely underweight $(3.3 \%)$. These findings were also reflected in the height for age indicator, where almost one third of the children $(27,3 \%)$ had a low height for age or risk a low height.

\section{Socio-economic determinants of food security}

Our statistical analysis highlighted a number of key determinants of food insecurity and poor nutritional status among urban children in Quibdó (all detailed results are clearly described in Table 3 ). Overall, older children, girls and non-afro (indigenous or white) were more likely to have a lower food security and nutritional status than others. Children with at least one parent missing, children from male-headed households, children with at least one parent involved in mining and children from "conflict schools" had a lower food security and

Table 2: Food security indicators, values found in this study and comparison with the national mean

\begin{tabular}{l|l|l}
\hline Variable & $\begin{array}{l}\text { Value obtained } \\
\text { for Quibdó in } \\
\text { this study }\end{array}$ & $\begin{array}{l}\text { National } \\
\text { Average } \\
\text { (Fonseca et al., } \\
2010 \text { ) }\end{array}$ \\
\hline Prevalence of obesity and overweight among adolescents & $20 \%$ & $19,2 \%$ \\
Prevalence of low height for age among adolescents & $27,5 \%$ & $7,9 \%$ \\
Perceived food insecurity by adolescents & $78 \%$ & $42,7 \%$ \\
Percentage of consumption of dairy products & $49 \%$ & $61 \%$ \\
Percentage of consumption of sweet/honey & $63 \%$ & $36,6 \%$ \\
Percentage of consumption of starchy food & $36 \%$ & NA \\
Percentage of consumption of legumes & $30 \%$ & $28,1 \%$ \\
Percentage of consumption for fruits & $39 \%$ & $66,8 \%$ \\
Percentage of consumption for grains & $27 \%$ & NA \\
Percentage of consumption for fat & $61 \%$ & NA \\
Percentage of consumption for cereals & $46 \%$ & NA \\
\hline
\end{tabular}


nutritional status than others. Children from poorer households, from larger households, and from households where one or both parents were un-employed were more likely to be food insecure and suffer lower nutritional status characteristics than others. However, children from households with a higher household size had a higher food diversity score.

The mean food diversity score among children was equal to 5,6 out of 11 $(s d=1.88)$. The day before the interview, the majority of children had eaten meat/poultry/offal or fish $(90 \%)$, sweets/honey (63\%) and cereals (61\%). Dairy products were consumed by $49 \%$ of the children, fat by $46 \%$, fruits by $39 \%$, starchy food by $36 \%$, legumes by $30 \%$ and grains by $27 \%$.

Using the body mass index (BMI) as a proxy for the nutritional status of children showed the co-existence of both underweight and obese children. A total of $20.6 \%$ of the children were obese $(5.6 \%)$ or overweight $(15.0 \%)$ and $14.0 \%$ of the children were either underweight $(11.3 \%)$ or severely underweight (3.3\%). These findings were also reflected in the height for age indicator, where almost one third of the children $(27,3 \%)$ had a low height for age or risk a low height.

\section{Socio-economic determinants of food security}

Our statistical analysis highlighted a number of key determinants of food insecurity and poor nutritional status among urban children in Quibdó (all detailed results are clearly described in Table 3). Overall, older children, girls and non-afro (indigenous or white) were more likely to have a

Table 3: Results of the GLM showing the correlations between social, conflict related and poverty related variables and food security indicators.

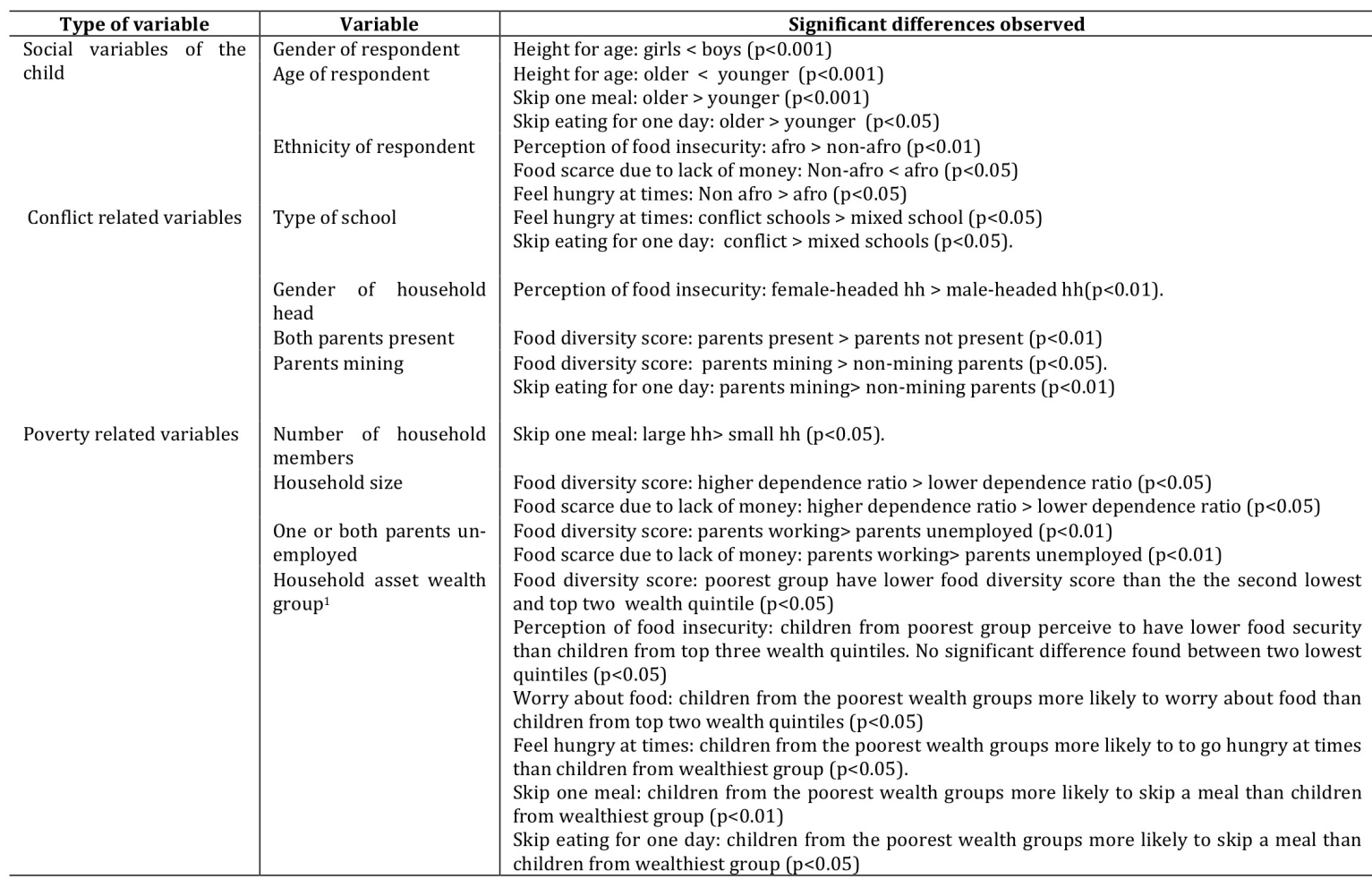


lowerfood security and nutritional status than others. Children with at least one parent missing, children from male-headed households, children with at least one parent involved in mining and children from conflict schools had a lower food security and nutritional status than others. Children from poorer households, from larger households, and from households where one or both parents were un-employed were more likely to be food insecure and suffer lower nutritional status characteristics than others. However, children from households with a higher household size had a higher food diversity score.

\section{Contribution of wild animals to the food security of children}

Wild animals had been consumed by $17.4 \%$ of children (wildmeat $=2.1 \%$ and wild fish $=15.3 \%$ ) during the day prior to the interview making it the third most important food source consumed by the children after industrial chicken $(26,7 \%)$ and sausages $(21.0 \%)$. While fish was mostly consumed on an ordinary basis, $21,8 \%$ of children mentioned that wildmeat was mostly consumed for special events.

As many as 16 fish species, including 8 freshwater species were mentioned (while $17 \%$ of the children did not know the name of the species of fish consumed). The five most consumed wild fish species were three freshwater fish: bocachico (Prochilodus magdalenae), cachama (Colossoma sp.) and dentón (Leporinus myscorum). Thirteen species of wildmeat were mentioned with the most commonly consumed species being paca (Cuniculus paca), armadillo (Dasypus novcinctus) and agouti (Dasyprocta sp.).

Children from the poorest wealth group were significantly more likely to have consumed wildmeat or wild fish the day before the interview than children from the wealthiest group $(p<0.001)$. The consumption of wild animals had a positive effect on food diversity $(p<0.001)$ but did not affect any of the other food security/nutritional status indicators (BMI, health/age, food security perception) (all $p>0.05)$. The calculation of the animal protein diversity index showed that removing wild animals from the diet would reduce the animal protein diversity score by half $(\mathrm{H} 2$ twice as higher than $\mathrm{H} 1$ value).

\section{RESULTS AND DISCUSSION}

\section{Discussion}

Based on standard indicators and thresholds adapted for Colombia, our analysis highlights a high level of food insecurity and poor nutritional status of urban children in Quibdó. The situation in Quibdó is worse than the national average for most of the variables assessed (Fonseca-Centeno et al., 2010), particularly for perceived food insecurity and prevalence of obesity and overweight. As observed in other regions, poor food security and nutritional status is mainly observed among the poorest households and/or households experiencing the consequences of conflict (households with only one parent present, female-headed households, households from neighbourhoods resulting from migrating populations flying from the conflict in rural areas etc) shows that food insecurity is related to the long lasting conflicts in the city (Zakari et al., 2014; Wood \& FelkerKantor, 2013; Joshi \& Joshi, 2017; Schmeer et al., 2015) and to the high level of poverty which results in such contexts (Ibáñez \& Moya, 2010, Calderón \& Ibáñez, 2009).

Our results clearly suggest that wild animals remain important elements of 
children's nutrition in Quibdó, particularly for the poorer households and represent the third most important source of protein in the diet. In this study, we also show that the consumption of wild animals increases dietary diversity, as also shown in Laos (Krahn, 2003), in South Africa (Cloete \& Idsardi, 2013), in Democratic Republic of Congo (de Merode et al., 2004; Termote et al., 2012) and in Cameroon (Sneyd, 2013). As such, through the diversification of diets, wild animals contribute to fill some of the micronutrient gaps, which could otherwise lead to significant effects on human growth, immune system function, mental health and cognitive development (Kennedy et al., 2003; Dounias \& Froment, 2011). While, wild animals are known as healthy food items (van Vliet et al., 2017), their consumption plays a safety net role among teenagers in Quibdo but does not guaranty food secure diets on its own.

If wild animals were to disappear from the diets (e.g. because of continued biodiversity loss), and no adequate measures are put in place to replace them by other healthy proteins, local diets would suffer from micronutrient deficiencies. This so called 'hidden hunger' is an issue that has often been overlooked in public policy (Kennedy et al., 2003) and requires particular attention to avoid a vicious cycle leading to further poverty and violence. Indeed, while food insecurity often results from conflict, the opposite is also true. In order to enhance food security in post conflict regions, the role that wild animals play for the food security of urban dwellers needs to be better recognized and translated into efforts to integrate biodiversity conservation and food security strategies in the peace process in which Colombia has engaged since 2016 (Baptiste et al., 2017).

\section{Acknowledgements}

This work would not have been possible without the support from the school directors, parents and children who accepted to participate in this study. We are grateful to UKAID and USAID for their financial support for this study. This work was carried out under the Bushmeat Research Initiative from CGIAR Forest Trees and Agro forestry program.

\section{REFERENCES}

Arnold JM, Pérez MR (2001). Can non-timber forest products match tropical forest conservation and development objectives? Ecological economics, 39(3), 437-447.

Arnold M, Powell B, Shanley P, Sunderland TCH (2011). Editorial: Forests, biodiversity and food security. International Forestry Review, 13(3), 259-264.

Bailey KV, Ferro-Luzzi A (1995). Use of body mass index of adults in assessing individual and community nutritional status. Bulletin of the World Health Organization, 73(5), p.673.

Baptiste B, Pinedo-Vasquez M, Gutierrez-Velez $\mathrm{VH}$, Andrade GI, Vieira P, Estupiñán-Suárez LM, and Lee TM (2017). Greening peace in Colombia. Nature Ecology \& Evolution, 1, 0102.

Beyers RL, Hart JA, Sinclair ARE, Grossmann F, Klinkenberg B, Dino S (2011). Resource Wars and Conflict Ivory: The Impact of Civil Conflict on Elephants in the Democratic Republic of Congo - The Case of the Okapi Reserve. PLoS ONE 6(11): e27129. doi:10.1371/journal.pone.0027129.

Bharucha Z, Pretty J (2010). The roles and values of wild foods in agricultural systems. Philosophical Transactions of the Royal Society B: Biological Sciences, 365(1554), 2913-2926.

Brncic TM, Amarasekaran B, McKenna A (2010) Sierra Leone national chimpanzee census. FreetownSierra Leone: Tacugama Chimpanzee Sanctuary .

Burlingame LJ (2000). Conservation in the Monteverde zone. Monteverde: ecology and conservation of a tropical cloud forest, 351388. 
Bvenura C, Afolayan AJ. 2015. The role of wild vegetables in household food security in South Africa: A review. Food Research International 76: 1001-1011.

Calderón V, Ibáñez AM (2009). Labor market effects of migration-related supply shocks: Evidence from internally displaced populations in Colombia. CEDE, Centro de Estudios sobre Desarrollo Económico, Facultad de Economía, Universidad de los Andes.

Cloete PC, Idsardi EF (2013) Consumption of indigenous and traditional food crops: Perceptions and realities from South Africa. Agroecology and sustainable food systems, 37(8), 902-914.

DANE - Departamento Administrativo Nacional de Estadística (2010) Censo nacional demográfico. Bogotá, Colombia.

DANE - Departamento Administrativo Nacional de Estadística (2007) Colombia: una nación multicultural - Su diversidad étnica -. Bogotá, Colombia.

Defensoría del pueblo (2014) Crisis Humanitaria en el Chocó. Diagnostico, valoración y acciones de la Defensoría del Pueblo.

De Lleras CDF (2010). Encuesta Nacional de la Situación Nutricional de la Situación en Colombia.

De Merode E, Homewood K, Cowlishaw G (2004). The value of bushmeat and other wild foods to rural households living in extreme poverty in Democratic Republic of Congo. Biological conservation, 118(5), 573-581.

De Merode E, Smith JH, Homewood K, Pettifor $R$, Rowcliffe M and Cowlishaw G (2007) The impact of armed conflict on protected-area efficacy in Central Africa. Biology letters, 3(3), 299-301.

Dounias $E$ and Froment $A$ (2011) From foraging to farming among present-day forest huntergatherers: consequences on diet and health. International Forestry Review, 13(3), 294-304.

Dudley JP, Ginsberg JR, Plumptre AJ, Hart JA and Campos LC (2002) Effects of war and civil strife on wildlife and wildlife habitats. Conservation Biology, 16(2), 319-329.

Escobedo R and Guío N (2015) Oro, crimen organizado y guerrillas en Quibdó. Fundación Ideas para la Paz. [online] URL: http://www.ideaspaz.org/publications/posts/1154.
FAO (2010) The state of food insecurity in the world: Addressing food insecurity in protracted crises. Rome. [online] URL: http://www.fao.org/docrep/013/i1683e/i1683e.pdf

Fonseca-Centeno Z., Heredia-Vargas AP, Ocampo-Téllez R, Forero-Torres Y, SarmientoDueñas OL and Álvarez-Uribe MC (2011) Encuesta Nacional de la Situación Nutricional en Colombia 2010-ENSIN. Bogotá, DC: Instituto Colombiano de Bienestar Familiar.

Fonseca-Centeno Z, Heredia A, Ocampo P, Torres Y, Sarmiento O and Álvarez M (2010) Encuesta Nacional de Situación Nutricional en Colombia, ENSIN; Resumen Ejecutivo. [online] URL:

http://www.javeriana.edu.co/documents/245769/3 025871/Resumen_Ejecutivo_ENSIN_2010.pdf/1 60e9856-006d-4a600-9da3-d7 1606703609

Golden CD, Fernald LC, Brashares JS, Rasolofoniaina BR and Kremen C (2011) Benefits of wildlife consumption to child nutrition in a biodiversity hotspot. Proceedings of the National Academy of Sciences, 108(49), 19653-19656.

Hadley C, Belachew T, Lindstrom D and Tessema $F$ (2009) The forgotten population? Youth, food insecurity, and rising prices: implications for the global food crisis. NAPA Bulletin, 32: 77-91. doi:10.1111/j.15564797.2009.01029.x.

Hadley C, Lindstrom D, Tessema F, and Belachew T (2008) Gender bias in the food insecurity experience of Ethiopian adolescents. Social science \& medicine, 66(2), 427-438.

Hatton J, Couto M and Oglethorpe JJ (2001) Biodiversity and war: a case study of Mozambique. Washington, DC: Biodiversity Support Program.

Hernández-Romero A (2005) La visibilización estadística de los grupos étnicos colombianos. Bogotá: Departamento Administrativo Nacional de Estadística (DANE).

Hickey R, Compton L, Moscardi E, Espinoza W, De Janvry A, Kassam A and Mata HD (2016) Informe anual 2015 del IICA: agricultura, oportunidad de desarrollo en las Américas (No. IICA E14). IICA, San José (Costa Rica). 
Ibáñez AM and Moya A (2010) Vulnerability of victims of civil conflicts: empirical evidence for the displaced population in Colombia. World Development, 38(4), 647-663.

Ickowitz A, Powell B, Salim MA and Sunderland TC (2014) Dietary quality and tree cover in Africa. Global Environmental Change, 24, 287294.

Idrobo, N., Mejía D and Tribın AM (2013) Minería ilegal y violencia en Colombia. Bogota, D.C.: Presentation delivered at the "International Conference Minería en Latinoamerica: retos y oportunidades", Bogota. May 23rd and 24th, Universidad de los Andes.

Idrobo N, Mejía D, Tribin AM (2014) Illegal Gold Mining and Violence in Colombia. Peace Economics, Peace Science and Public Policy, 20(1), 83-111.

Joshi GR and Joshi NB (2017) Determinants of household food security in the eastern region of Nepal. SAARC Journal of Agriculture, 14(2), 174188.

Kalpers J, Williamson EA, Robbins MM, McNeilage A, Nzamurambaho A, Lola $\mathrm{N}$, and Mugiri G (2003) Gorillas in the crossfire: population dynamics of the Virunga mountain gorillas over the past three decades. Oryx, 37(03), 326-337.

Kasper NM, Herran OF and Villamor E (2014) Obesity prevalence in Colombian adults is increasing fastest in lower socio-economic status groups and urban residents: results from two nationally representative surveys. Public health nutrition, 17(11), 2398-2406.

Kennedy G, Nantel G and Shetty P (2003) The scourge of " hidden hunger": global dimensions of micronutrient deficiencies. Food Nutrition and Agriculture, (32), 8-16.

Krahn J (2003) Cooking up dietary change in Lao upland kitchens. Juth Pakai, 1(1), 3-13.

Lawrence MJ, Stemberger HL, Zolderdo AJ, Struthers DP, and Cooke SJ (2015) The effects of modern war and military activities on biodiversity and the environment. Environmental Reviews, 23(4), 443-460.

Murrieta RSS, and Dufour DL (2004) Fish and farinha: protein and energy consumption in Amazonian rural communities on Ituqui Island, Brazil. Ecology of Food and Nutrition, 43(3), 231-255.
Nackoney J, Molinario G, Potapov P, Turubanova S, Hansen MC, and Furuichi T. (2014) Impacts of civil conflict on primary forest habitat in northern Democratic Republic of the Congo, 1990-2010. Biological Conservation, 170, 321328.

Nasi R, Taber A, and van Vliet N (2011) Empty forests, empty stomachs? Bushmeat and livelihoods in the Congo and Amazon Basins. International Forestry Review, 13(3), 355-368.

Niclasen B, Molcho M, Arnfjord S, and Schnohr C (2013) Conceptualizing and contextualizing food insecurity among Greenlandic children. International Journal of Circumpolar Health, Vol.72.

Parra DC, lannotti L, Gomez LF, Pachón H, Haire-Joshu D, Sarmiento OL and Brownson RC (2015). The nutrition transition in Colombia over a decade: a novel household classification system of anthropometric measures. Archives of Public Health, 73(1), 12.

Pengpid S, and Peltzer K (2014) Prevalence of overweight/obesity and central obesity and its associated factors among a sample of university students in India. Obesity research \& clinical practice, 8(6), e558-e570.

Pino N, Valois-Cuesta H, and Cuesta J (2004) Especies vegetales utilizadas para la elaboración de artesanías en el departamento del Chocó-Colombia. Revista Institucional Universidad Tecnológica del Chocó, 21, 9-18.

Plumptre AJ, Bizumuremyi JB, Uwimana F, and Ndaruhebeye JD (1997) The effects of the Rwandan civil war on poaching of ungulates in the Parc National des Volcans. Oryx, 31(4), 265-273.

Poole-Di Salvo, E., Silver, E.J. and Stein, R.E. (2016) Household Food Insecurity and Mental Health Problems Among Adolescents: What Do Parents Report?. Academic pediatrics, 16(1), pp.90-96.

Quiceno MP, van Vliet N, Moreno J, and Cruz D (2015) Diagnóstico sobre el comercio de carne de monte en las ciudades de Colombia. CIFOR occasional paper, Vol. 136. CIFOR.

Ramirez-Gomez SO, Torres-Vitolas CA, Schreckenberg K, Honzák M, Cruz-Garcia GS, Willcock S and Poppy GM (2015) Analysis of ecosystem services provision in the Colombian Amazon using participatory research and mapping techniques. Ecosystem Services, 13, 93-107. 
Ramirez-Luna ÁV (2013) The exclusive fishing zone for the artisanal fishery in Chocó Colombia: origins, development, and consequences for artisanal fisheries and food security. Doctoral dissertation, Memorial University of Newfoundland.

Reyes-García V, Menendez-Baceta G, AceitunoMata L, Acosta-Naranjo R, Calvet-Mir L, Domínguez P. and Rodríguez-Franco R (2015) From famine foods to delicatessen: Interpreting trends in the use of wild edible plants through cultural ecosystem services. Ecological Economics, 120, 303-311.

Sarti FM, Adams C, Morsello C, van Vliet N, Schor T, Yagüe B, and Cruz D (2015) Beyond protein intake: bushmeat as source of micronutrients in the Amazon. Ecology and Society, 20(4).

Schmeer KK, Piperata BA, Rodríguez AH, Torres VMS, and Cárdenas FJC (2015) Maternal resources and household food security: evidence from Nicaragua. Public health nutrition, 18(16), 2915-2924.

Schulte-Herbrüggen B, Cowlishaw G, Homewood $\mathrm{K}$, and Rowcliffe JM (2013) The importance of bushmeat in the livelihoods of West African cash-crop farmers living in a faunallydepleted landscape. PloS ONE, 8(8), e72807.

Scoones I, Melnyk M, and Pretty JN (1992) The hidden harvest: wild foods and agricultural systems. A literature review and annotated bibliography.

Seligman HK, Laraiaand BA, and Kushel MB (2010) Food insecurity is associated with chronic disease among low-income NHANES participants. The Journal of Nutrition, 140(2), 304-310.

Shackleton N (2015) Is there a link between low parental income and childhood obesity? Journal of Early Childhood Research, 1-18 $1476718 \times 15606479$.

Sneyd LQ, Legwegoh A, and Fraser ED (2013) Food riots: Media perspectives on the causes of food protest in Africa. Food security, 5(4), 485-497.

Shumsky SA, Hickey GM, Pelletier B, and Johns $T$ (2014) Understanding the contribution of wild edible plants to rural social-ecological resilience in semi-arid Kenya. Ecology and Society, 19(4), 34.
Sunderland TCH (2011) Food security: why is biodiversity important? International Forestry Review 13(3).

Termote C, Meyi MB, Djailo BDA, Huybregts L, Lachat C, Kolsteren P, and Van Damme P (2012)

A biodiverse rich environment does not contribute to a better diet: a case study from DR Congo. PloS One, 7(1), e30533.

Vanegas L, van Vliet N, Cruz D and Sandrin F. 2016. Contribución proteica de animales silvestres y domésticos a los menús de los contextos rurales, peri-urbanos y urbanos de varias regiones de Colombia. Biota Colombiana, 17(1).

van Vliet N, Quiceno-Mesa MP, Cruz-Antia D, Tellez L, Martins C, Haiden E, and Bonilla T (2015) From fish and bushmeat to chicken nuggets: the nutrition transition in a continuum from rural to urban settings in the Tri frontier Amazon region. Ethnobiology and Conservation, 4: 1-6

Van Vliet N, Moreno J, Gómez J, Zhou W, Fa JE, Golden C, Alves RRN, Nasi R (2017) Bushmeat and human health: Assessing the Evidence in tropical and sub-tropical forests. Ethnobiology and Conservation 6:1-45.

Valderrama N, Castro C, Díaz M, Albarracín R, Bernal Y, and García N (2014) Plantas alimenticias y medicinales nativas de Colombia. Instituto de Investigación de Recursos Biológicos Alexander von Humboldt. [online] URL: http://i2d.humboldt.org.co/ceiba/resource.do? $r=c$ olombia_magnoliophyta_2014

Verwimp P and Muñoz-Mora JC (2013) Returning home after civil war: Food security, nutrition and poverty among Burundian households. Households in Conflict Network, Working Paper, 123.

Vinceti B, Ickowitz A, Powell B, Kehlenbeck K, Termote C, Cogill B, and Hunter D (2013) La contribución de los bosques a las dietas sostenibles. Los Bosques para la Seguridad Alimentaria y Nutricional, 64(2), 54.

Vogel G (2000) Conflict in Congo threatens bonobos and rare gorillas. Science, 287 (5462),2386-2387.

Wood CH, and Felker-Kantor EL (2013) The Color of Hunger: Food Insecurity and Racial Inequality in Brazil. Latin American and Caribbean Ethnic Studies, 8(3), 304-322. 
Yamagiwa J (2003) Bushmeat poaching and the conservation crisis in Kahuzi-Biega National Park, Democratic Republic of the Congo. Journal of Sustainable Forestry, 16(3-4), 111-130.
Zakari S, Ying L, and Song B (2014) Market integration and spatial price transmission in Niger grain markets. African Development Review, 26(2), 264-273

Received: 06 September 2017

Accepted: 23 November 2017

Published: 19 December 2018 